\title{
記述式項目の使用に関する教育測定学的考察
}

\author{
野 澤 雄 樹 \\ (ベネッセ教育総合研究所)
}

\section{Considerations for Use of Constructed-Response Items in Educational Achievement Tests}

\section{YUKI NOZAWA}

(BENESSE EDUCATIONAL RESEARCH AND DEVELOPMENT INSTITUTE)

\begin{abstract}
As constructs measured by achievement tests shift from basic knowledge and skills to higher-order thinking skills, the use of constructed-response (CR) items has increased. This tendency is salient in the United States where selected-response (SR) items have been widely used, but a similar movement can also be found in Japan. The development and administration of a test would become complicated if a test consists of both SR and CR items (i.e., mixed-format). It seems necessary to enhance the theory and practice of educational measurement to handle the new challenges. In this paper, three issues concerned with the use of CR items are discussed: (1) the effect of item format on the measurement, (2) the equating of mixed-format tests, and (3) an examination of the consequences of test use. In each discussion, implications for validity and validation are emphasized. In the last section, some additional considerations are provided.
\end{abstract}

Key Words: item format, constructed-response, validity, equating, mixed-format

テストが測定対象とする学力が, 基礎的な知識・技能を中心としたものから高次思考スキルを重視し たものに移行するのに伴い, 受験者に解答の生成を求める形式の項目が多用されるようになってきてい る。この傾向は歴史的に選択式項目が広く用いられてきた米国において顕著であるが，国内においても， 大学入学共通テストで部分的に記述式項目が出題されることになるなど, 類似した動きが見られる。一 方で, 記述式項目を含んだテストの運用にはさまざまな課題が存在しており, それらを解決するために 教育測定の理論面および実践面での強化が求められる。本稿では, 記述式項目を使用する際に考慮すべ き教育測定学的なテーマのうち，（a）項目形式が測定に与える影響，（b）記述式項目を含んだテストに おける等化，（c）テストの使用がもたらす結果の検証，の3つを取り上げた。これらのテーマは，国内 では議論されることが少ないものの, 妥当性との関連が深い重要なテーマである。各テーマについて, 研 究が進んでいる米国での議論を参考に, 今後必要となる研究について考察した。全体考察では, 日米の 違いや，国内の教育測定学が抱える課題について指摘した。

キーワード : 項目形式, 記述式, 妥当性, 等化, 混合形式

\section{はじめに}

教育場面で広く用いられるアチーブメント型のテス トでは, 目的に応じてさまざまな形式の問題が出題さ
れる。テストで出題される問題は, テスト項目あるい は単に項目と呼ばれる。項目は, 解答形式の違いに よって解答選択式 (selected-response) と解答構築式 (constructed-response) に大別される (Haladyna \& Rodriguez, 
2013)。解答選択式は与えられた選択肢の中から解答を 選ぶ形式の項目であり, 受験者の解答のバリエーショ ンを限定できるという特長がある。解答のバリエー ションが限定されれば，どの解答を正答とし，どの解 答を誤答とするか明確に定めることができるため, 正 確かつ高速で，再現性の高い採点が可能になる。解答 選択式のもう 1 つの特長は，1 項目あたりの所要時間 が比較的短いため，限られた時間で多くの項目を出題 できることである。一般に項目数が増えるほど観測得 点の分散に占める誤差分散の割合は小さくなり，信頼 性 (測定精度) は高くなる。また, 項目数が多いほうが 出題内容の偏りを防ぎやすくなるため, 実施回ごとに 異なるテスト版 (項目セット) を使用するような場合に, 得点の比較可能性 (comparability) を確保しやすくなる (Haertel \& Linn, 1996)。

一方, 解答構築式は受験者に解答の生成を求める形 式の項目であり, 単語レベルで解答できる項目から, 数十一数百字程度の記述を求める項目, 問題解決のプ ロセスを記述させる項目，テストの枠を超えたレポー 卜作成やプレゼンテーションなどの課題, さらには ポートフォリオ評価を含める場合もある (Bennett, 1993; Bennett, Ward, Rock, \& LaHart, 1990; Haladyna \& Rodriguez, 2013; Snow, 1993)。解答構築式の項目を使用する利点の 1 つ は，測定したい構成概念 (construct) をより直接的な形 で問うことができることである。例えば，ある授業を 通じて大学生が論理的な文章作成力を身に付けたか知 りたいときに，文法・語法や論理学の知識を解答選択 式の項目で問うよりも，実際に論理的な文章を書かせ てみるほうが，少なくとも表面的には，意図した構成 概念に近いものを測定しているように見える。Messick （1989）は妥当性に対する脅威の 1 つとして，テストが 構成概念の重要な次元や相を十分に捉えていない状態, つまり構成概念の代表性不足 (construct underrepresentation）を挙げているが，「モチベーションを維持しながら 文章を最後まで書き上げる」といった実際の行動を伴 う次元や相を捉えたい場合には，解答構築式のほうが 適していると思われる。

解答構築式の項目を実際のテストで出題しようとす ると, さまざまな困難が生じる。困難の 1 つは, 単語 レベルで解答できるような項目を除けば, 正解のバリ エーションが無数に存在するため, 機械的な採点が難 しいことである。そのため, 特に記述量が多い複雑な 項目の採点は, 測定領域に詳しい専門家が, ルーブ リックと呼ばれるガイドラインに基づいて行うことが 多い (Johnson, Penny, \& Gordon, 2009)。学校単位で実施す
る定期テストの規模であれば，採点の労力や費用はそ れほど問題にならないが，大規模テストの場合には， 採点者の長期的な確保や定期的なトレーニングが必要 になるため，労力・費用ともに膨大になる。採点の一 貫性に関しては，解答を構成要素に分けるのではなく， 全体を 1 つまとまりとして評価するホリスティック 採点 (holistic scoring) の手法が開発されたことや, 採点 者のトレーニングおよび品質管理の技術が進んだこと により，ハイステイクスなテスト運用にも耐えられる 水準になってきている（米国のテスト団体である Educational Testing Service が採点精度の向上に果たした歴史的な役割につい ては, Bejar, 2017 を参照)。しかし，例えば Fitzpatrick， Ercikan, Yen, \& Ferrara（1998）が指摘しているように, テストの各実施回では一貫した採点ができていても， 過去の実施回における採点を後から忠実に再現するこ とは難しいとされる。

もう 1 つの困難は, 解答構築式の項目は 1 項目あた りの所用時間が長いため, 出題できる項目数が限られ ることである。先ほどの例で, 大学生に論理的な文章 を書かせることになったとしても，時間的な制約など により，実際に出題できるのは 1 - 2 項目が限度である と思われる。その場合, 例えば「因果関係と相関関係 の違いを理解しているか」といった重要な評価観点が, 題材によっては十分に観測できないことが起こり得る。 また, 一般に項目数が少ないほど, 受験者と項目の交 互作用（相性など）による得点変動は大きくなる。項目 数の少なさに起因する信頼性の低さや, 出題内容の偏 りによる比較可能性の低さに対する懸念は, 多くの研 究者によって指摘されている (e.g., Brennan \& Johnson, 1995; Dunbar, Koretz, \& Hoover, 1991; Gao, Shavelson, \& Baxter, 1994; Haertel \& Linn, 1996; Shavelson, Baxter, \& Gao, 1993; ただ し, Bridgeman, 2016 のような反論もある)。そのため, 解答 構築式の項目のみでテストを構成するよりも, 解答選 択式の項目をうまく併用することで, それぞれの長所 を生かしつつ短所をカバーするほうが, 現実的なテス 卜設計であると考えられる（Martinez, 1999; Messick, 1993）。 異なる形式の項目を組み合わせて構成されるテストは 混合形式 (mixed-format) と呼ばれる。

\section{用語の整理}

米国では “selected-response,” “constructed-response” という用語は標準的に使用されており，それぞれ SR, CR と略されることが多い。しかし，その日本語訳で ある「解答選択式」，「解答構築式」はやや元長であり， 用語として使いやすいとは言えない。そのため, 本稿 
の以下では，解答選択式を「選択式」と略して使用す る。また, 解答構築式の項目のうち, 記述による解答 を求める項目を「記述式」と呼び, 本稿の主要な考察 対象とする。測定領域は特に限定せず, 数学や理科に おいて解法プロセスを記述させる項目なども記述式に 含める。一方, 記述を求めるものであっても, テスト の枠を超えるレポート作成などの課題や，コンピュー 夕を活用した革新的な項目 (シミュレーション型の項目やイ ンタラクティブな項目など）は記述式に含めない。選択式 項目のみで構成されたテストを「選択式テスト」, 記述 式項目のみで構成されたテストを「記述式テスト」, 両 方の形式の項目を含むテストを「混合形式テスト」と 呼ぶことにする。

\section{米国および日本における動き}

米国では歴史的に選択式項目が広く用いられてきた が, 現在は記述式項目をはじめとして, より革新的な 項目を使用する方向に動いている。例えば, 全米共通 学力基準 (Common Core State Standards) に対応して新し く開発された Partnership for Assessment of Readiness for College and Careers (PARCC) および Smarter Balancedの 2 つのテストでは, 記述式項目が多用されて いる (Darling-Hammond, 2017)。また, 全米学力調査 (National Assessment of Educational Progress; NAEP) では, コ ンピュータを活用したインタラクティブな項目の研究 が行われている (Agard \& von Davier, 2018)。これらの動 きの背景として, 生徒や学生に求められる学力が批判 的思考力や問題解決力などの高次思考スキル (higherorder thinking skills; e.g., Schraw, McCrudden, Lehman, \& Hoffman, 2011）を重視したものに移ってきていること, 高次思考スキルの測定は選択式項目では難しいと考え られていることが挙げられる (Darling-Hammond, 2014; Stecher, 2014)。

国内においても同様の動きが見られる。大学入試セ ンター試験の後継として導入される大学入学共通テス トでは, 国語と数学 (数学は一部科目) において記述式項 目が出題される予定である（文部科学省, 2017）。この決定 に先立つ中央教育審議会答申では, 現行の大学入試セ ンター試験は「知識・技能」を問う項目が中心である とした上で，「知識・技能」と「思考力・判断力・表現 力」を総合的に評価するために，新テストの導入およ び新テストにおける記述式項目の使用が提言されてい る（中央教育審議会, 2014）。また, 高大接続システム改革 会議の最終報告では,「思考力・判断力・表現力」を測 定するために記述式項目を出題することが明確に述べ られている（高大接続システム改革会議, 2016)。「思考力 ·
判断力・表現力」を米国における高次思考スキルに相 当するものと考えれば, その測定のために記述式項目 を使用するという大学入試改革の動きは, 米国におけ る動きと重なる部分が大きいと言える。

\section{本稿の目的}

社会で必要とされる学力が高次思考スキルを重視し たものに移行する中, テストで使用される項目にも変 化が求められるのは当然のことである。しかし, 例え ば宇佐美 (2013a) や渡部・平・井上（1988）が指摘して いるように，国内においては，オーソドックスな記述 式項目についてでさえ, その使用を支える測定学的な 研究が十分に行われているとは言い難い状態である。 そこで本稿では, 記述式項目を使用する際に考慮すべ きさまざまなテーマの中から，(a) 項目形式が測定に 与える影響, （b）混合形式テストにおける等化，（c） テストの使用がもたらす結果の検証, の 3 つを取り上 げ，研究が先行している米国での議論を参考にしなが ら, 今後必要になる研究の方向性について考える。

テーマ 1 は記述式項目を使用する理由として挙げら れる「高次思考スキルの測定に適している」という主 張が, 証拠によって裏付けられている程度を確認する ものである。この主張は多くの議論の前提となるもの であるため，最初に検討しておく必要がある。しかし， 現時点では高次思考スキル自体が明確に定義されてい るとは言い難いため, ここでは「記述式項目は選択式 項目と比べて複雑な認知プロセスを捉えているか」と いうリサーチクエスチョンに読み替えて検討する。 テーマ 2 はやや技術的な内容になるが, テストの結果 が実施回間で比較できるかどうかは, 記述式項目を使 用したテストの有用性に大きく影響する。また, 現在 主流の妥当性概念がテスト得点の解釈の適切さに重点 を置いていることを考えれば (e.g., Kane, 2006; Messick, 1989), 得点の比較可能性を高める等化は, 妥当性の観 点からも重要なテーマであると言える。テーマ 3 はテ ストの使用がもたらす結果 (consequences) も妥当性の 範囲に含めるとする米国のテストスタンダード（Standards for Psychological and Educational Testing; American Educational Research Association [AERA], American Psychological Association [APA], \& National Council on Measurement in Education $[\mathrm{NCME}]$, 2014）に従うものである。テストの使用が もたらす結果としてテストの開発者や使用者が検証す ベき事項について考える。 


\section{テーマ 1：項目形式が測定に与える影響}

\section{量的研究の歴史}

選択式テストと記述式テストが同じ構成概念を測 定しているか検討した研究の歴史は古く, 1920 年代 にまで遡ることができる (Frederiksen, 1984; Hogan, 1981; Rodriguez, 2003; Traub, 1993)。Hogan（1981）は 1980 年代 初頭までに行われた研究のうち, コミュニケーション スキル（読む，書く，話す）に関するものを除いた約 40 件についてレビューしている。これらの研究では, 同 じ内容を問うように作成された異なる形式のテストを 同一の受験者群に実施し，得点間の相関係数を求め るという方法が多く用いられていた。Hogan (1981) は, これらの研究から得られた希薄化の修正後の相関係数 が概ね高い值だったことから，多くの場合に選択式テ ストと記述式テストは等価 (equivalent) な測度であると している。

Frederiksen (1984) は, 先行研究で項目形式の効果が はっきりと見られない理由として, 選択式項目を元に 記述式項目を作成している点を挙げている。選択式項 目は複雑な認知プロセスを測定しているものが少ない ため, 選択式項目から記述式項目を作成する場合, ど ちらも複雑な認知プロセスを測定していないことにな り，項目形式による差は見られなくなる。Frederiksen （1984）は，複雑な認知プロセスの測定を意図した記述 式項目から選択式項目を作成した研究（Frederiksen \& Ward, 1978; Ward, Frederiksen, \& Carlson, 1980) では，項目形 式による差が見られたとしている。

Frederiksen (1984) の主張を検証する形で, Bennett, Rock, \& Wang (1991) は混合形式テストである Advanced Placement Computer Science のデー夕を分 析している。この研究では, 選択式の 50 項目 (正答· 誤答の二值型項目）を内容が等しくなるように 10 項目ず つのまとまりに分け，それぞれで正答数得点を計算し て 5 つの変数を作成している。一方， 0-9 点で採点さ れる記述式の 5 項目は，そのまま変数として扱ってい る。本試験データからランダムに抽出した 2 つのデー タセット（受験者数は各 1,000 人）に対し，選択式の変数 と記述式の変数に異なる因子を仮定した二因子モデル を適用したところ, 因子間相関係数は. 97 および.93 と 高い值になった。Bennett et al. (1991) は，モデルの適 合度は二因子モデルのほうがよかったものの，一因子 モデルを採用するほうが適切であると結論付けている。 その上で，個々の選択式項目が 1 つ以上の認知プロセ スを測定しているとは考えにくいが，それらの項目を
複数足し合わせることで, 記述式項目が測定している 複雑な認知プロセスの多くを, ある程度の深さまで測 定できているのではないかと考察している。このデー 夕はThissen, Wainer, \& Wang (1994) によって再分析さ れ, 選択式項目をまとめた 5 変数と記述式項目の 5 変 数は 1 つの因子で大部分が説明できるものの, 記述式 項目の間に局所依存が残るため，それらを説明するた めに因子数を増やす必要があることが指摘されている。

Hancock (1994) は, 先行研究では項目の認知的な複 雑さが統制されていない点を指摘し, ブルームの分類 体系（Bloom, Engelhart, Furst, Hill, \& Krathwohl, 1956) に基 づいて, 知識, 理解, 適用, 分析の各カテゴリーにつ いて選択式テストと記述式テストを作成した。受験者 はある大学で教育測定入門 (クラス 1) と統計法入門 (ク ラス2）を受講していた大学生および大学院生であり (クラス 1 は 46 人, クラス 2 は 44 人), クラスごとに 8 種類 (4 カテゴリー $\times 2$ 項目形式) のテストを定期テストとして 実施した。その結果, テスト得点間の希薄化の修正後 の相関係数は, どちらのクラスにおいても 4 つのカテ ゴリーを通じて概ね高い值になった。また，クラスご

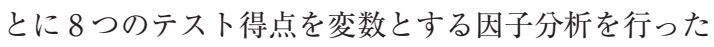
ところ, どちらのクラスにおいても第一因子が強いと いう結果が得られた。Hancock（1994）は, 項目を適切 に作成すれば，選択式テストであっても分析カテゴ リーまで測定できる可能性を指摘している。

RodrigueZ (2003) は 1998 年までに行われた 67 件の研 究をレビューし, 29 件の研究から 56 個の相関係数を 抽出した。これらの相関係数に希薄化の修正を行い, フィッシャーの $Z$ 変換を施したものを従属変数として 回帰分析を行っている。説明変数には, 選択式項目と 記述式項目が似ている程度を（1）問題文は同じで解答 形式だけ異なる幹等価（stem-equivalent）の場合 $(n=21)$, (2) 幹等価ではないが測定している内容は同じ場合 $(n=12)$ ，（3）異なる内容を測定していて記述式項目が 短答式である場合 $(n=8),(4)$ 異なる内容を測定して いて記述式項目がエッセイの場合 $(n=15)$, の 4 段階に 分けたものを使用している。また, 研究の出版時期お よび受験者群の年齢水準も説明変数として使用してい る。変量効果を含めたモデルで分析した結果, 希薄化 の修正後の相関係数の平均は, 項目の類似度順に.948 (95\% CI [.907,.971]), .915 (95\% CI [.837,.956]), .839 (95\% CI [.661, .927])，.810 (95\% CI [.674,.893]) であり， 幹等価の場合とそうでない場合の間で有意差が見られ た。一方, 出版時期と年齢水準に有意な効果は見られ なかった。Rodriguez (2003) は, 異なる形式のテストに 
よって測定される構成概念の等価性について, 部分的 には項目設計および作問者の意図によって決定される としている。

\section{認知プロセスを研究する必要性}

量的研究は 1970 年代後半から 1990 年代前半にかけ て盛んに行われており，ここで挙げた以外にもさまざ まな研究が行われている（e.g., Ackerman \& Smith, 1988; Traub \& Fisher, 1977; van den Bergh, 1990; レビューとしてTraub, 1993)。量的研究から示唆されることとして，(a) 幹等 価の場合は選択式テストと記述式テストの得点間で高 い相関が維持されること，（b）選択式項目を注意深く 作成し, それらを組み合わせることで, 複雑な認知プ ロセスを測定できる可能性があること，(c) 記述式項 目としてエッセイを使用した場合には相関が低くなる が，平均的にはそれほど低い值にはならないこと，な どが挙げられる。同じ構成概念を測定していると仮定 されるテスト間で得点の相関が高いことは, 収束的な 妥当性の証拠と呼ばれる (AERA et al., 2014)。収束的な妥 当性の証拠が示されている幹等価の場合は, 概ね同じ 構成概念を測定していることが示唆される。一方，記 述式項目としてエッセイを使用した場合には相関が低 めになることから, やや異なる構成概念を測定してい ることが示唆される。

量的研究から得られたこれらの結果は示唆に富むも のの, 「記述式項目は選択式項目と比べて複雑な認知プ ロセスを捉えているか」という問いに答えるのには十 分ではない。例えば収束的な妥当性の証拠が得られて いる幹等価の場合であっても, 得点の背後にある認知 プロセスが同じであることまでは意味しないからであ る。リサーチクエスチョンに答えるためには，それぞ れの形式の項目に解答しているときの認知プロセスを, より直接的な形で比較する必要がある。

受験者の解答プロセス (response process; 認知プロセスも 解答プロセスに含まれる) がテスト開発者の意図した通り であることを示す証拠は, 解答プロセスに基づく妥当 性の証拠（AERA et al., 2014）と呼ばれ, 妥当性を示す上 で重要な役割を果たすようになってきている（Ercikan \& Pellegrino, 2017; Zumbo \& Hubley, 2017)。解答プロセスを 研究するためのデー夕収集法は, 受験者に解答中の思 考内容を報告してもらう思考発話法 (think-aloud) や, 視線の動きを追跡して記録する方法, マウスやキー ボードの使用状況を記録する方法など, さまざまなも のが考案されている。以下では, 思考発話法を使用し て受験者の認知プロセスを調べた研究について概観し， リサーチクエスチョンに迫る手がかりを探すことにす
る。

\section{思考発話法を使用した研究の例}

思考発話法を使用して受験者の認知プロセスを調べ た研究は, 選択式項目を対象としたもの（e.g., Farr, Pritchard, \& Smitten, 1990; 益川他, 2018; Reich, 2009, 2013; Rupp, Ferne, \& Choi, 2006; Smith, 2017, 2018), 記述式項目を対象 としたもの（e.g., Baxter, Glaser, \& Raghavan, 1994; Magone, Cai, Silver, \& Wang, 1994), 両者を対象としたもの (e.g., Hamilton, Nussbaum, \& Snow, 1997; Katz, Bennett, \& Berger, 2000; Smith, Breakstone, \& Wineburg, 2018) に分けられる。 ここでは, 両者を直接的に比較していて結果が解釈し やすい Smith et al. (2018) と, 間接的な比較ではあるも のの示唆が多い Hamilton et al. (1997) について取り上 げる。

Smith et al.（2018）は歴史分野における思考力を測定 するために開発された History Assessments of Thinking (HATs) の記述式項目 (8 項目) と, それらを元に作 成された幹等価な選択式項目を比較している。高校生 26 人をそれぞれの項目形式にランダムに割り当て, 思 考発話法によるインタビューを行ったところ, どちら の形式の項目も構成概念に関連した認知プロセス（歴 史的思考プロセス）を捉えていた。しかし, 記述式項目の 場合は構成概念と無関倸な認知プロセスが少なかった のに対し, 選択式項目の場合はテスト方略（消去法によ る解答選択など）の使用が頻繁に確認された。また，選 択式項目を受験した高校生の多くは解答を考え付く前 に選択肢を確認しており, 歴史分野で求められる自力 で答えを見つけ出す力を測定できていないことが示唆 されている。さらに, 記述式項目における解答は発話 データの内容と一致していたのに対し, 選択式項目で 解答として選ばれた選択肢は必ずしも発話デー夕の内 容と一致しておらず, 誤った考えに基づいて正答選択 肢が選ばれるケースが確認されている。

Hamilton et al. (1997) は高校生 41 人に対して思考発 話法を適用し, 理科および数学の記述式項目に解答し ている最中の認知プロセスを研究している。シーソー を題材とした数学の記述式項目では, 多くの生徒は解 法を知らなかったが, 問題文に例と計算式が与えられ ており, また, 正確な計算結果を求めるように指示さ れていたため, 機械的に計算することで解答していた。 一方, この項目と類似した選択式項目には例が付与さ れていなかったため, 生徒は実体験から得た知識を活 用して解答しなければならなかった。その結果, 選択 式項目のほうが複雑な認知プロセスを必要とした可能 性が指摘されている。Hamilton et al.（1997）はまた, 選 
択式項目では化学, 物理, 生物の概念について高い理 解を示していた生徒が，類似した記述式項目ではその 知識を活用できないケースについて報告している。発 話デー夕の分析から，選択式項目が科学的な概念を 使って考えることを強制する構造だったのに対し，記 述式項目はそのような構造ではなかったため, どのよ うな解答が求められているのかわからなかった可能性 が指摘されている。

\section{思考発話法を使用した研究から得られる示唆}

選択式項目の解答時にテスト方略の使用が頻繁に見 られることは, 思考発話法を使用した他の研究でも報 告されている (e.g., 益川他, 2018; Rupp et al., 2006; Smith, 2017)。特に選択肢は, 問題文の意味や, 解答として何 が求められているのかを明らかにする手がかりとなる ため, それらを先に確認することは，問題解決の手段 として理にかなっていると言える。また，消去法など の方略も，正答する確率を高めるための合理的な手段 と言える。一方で, 構成概念が自力で解答を見つけ出 すことを求めている場合には，このようなテスト方略 の使用は，測定したい認知プロセスの発現を妨げ，妥 当性を低める要因となる。選択式項目は構造的にテス 卜方略の使用を防ぎにくいため，それらの影響を取り 除きたい場合には，記述式項目を使用するほうがよい と思われる。しかし, Hamilton et al. (1997) が示して いるように，項目内容に不備がある場合には，記述式 項目を使用しても目的の認知プロセスを捉えられると は限らない。また Katz et al.（2000）は，数学の記述式 項目においてテスト方略の使用が意外なほど多いこと を指摘している。これらの結果は，記述式項目であれ ば複雑な認知プロセスを問えるという単純な話ではな く，実際に作成された項目に依存することを示してい る。

\section{テーマ1のまとめと考察}

「記述式項目は高次思考スキルの測定に適している」 という前提について確認するために, 量的研究と思考 発話法を使用した研究を限定的にではあるがレビュー した。量的研究からは, 問題文が同じで解答形式だけ が異なる幹等価の場合には，選択式テストと記述式テ ストは概ね同じ構成概念を測定していることが示唆さ れた。一方, 思考発話法を使った研究 (Smith et al., 2018) では, 幹等価の場合でも受験者の認知プロセスには違 いがある可能性が示された。量的研究からはまた，記 述式項目としてエッセイを使用した場合は，選択式テ ストと記述式テストはやや異なる構成概念 (次元) を測 定していることが示唆された。記述式テストが測定し
ている次元のほうが複雑な認知プロセスに対応してい ると予想されるが，エッセイ項目は構成概念に関連し た認知プロセスを適切に捉えているか，無関係な認知 プロセスを排除できているか，といった点について知 るためには，追加的な研究が必要であると思われる。

思考発話法は受験者の認知プロセスを解明する上で 有効なアプローチであると思われる。国内では益川他 (2018) が, 大学入試センター試験の国語を対象に思考 発話法を使った研究を行っている。この研究は選択式 項目のみを対象としたものであるが，大学入試という ハイステイクスなテストの認知プロセスに踏み込んだ 意義は大きいと思われる。今後, 選択式項目と記述式 項目を直接比較した研究が増えることで, 項目形式の 効果がより明確になると思われる。しかし，思考発話 法を用いた研究は労力が大きいため, ある程度の規模 の研究体制がないと実行は難しい。研究を加速させる 1 つの案は, テスト開発を行う団体や機関が, 思考発 話法による認知プロセスの研究を開発工程に取り入れ ることである。正しく適用されれば，研究知見を高め つつ，質の高いテスト開発につながることが期待され る。

一方で, 思考発話法の安易な適用は, この方法に対 する信用を低め，有用性を下げる結果になりかねない (Leighton, 2004)。デー夕の収集方法や取り扱い, 倫理規 定の順守, 客観性を保つための分析手続きなど, 研究 実施者の専門的なトレーニングが必要になると思われ る。また, 思考発話法で得られた知見の頑健性につい ても研究する必要がある。思考発話法を用いることが 受験者の解答中の思考内容に大きな影響を与えないこ とを示した研究として例えばNorris (1990) があるが, これは英語話者に選択式項目を使用した場合の結果で ある。日本語話者に対して，特に記述式項目を使用し た場合にも同様の結果が得られるのかについては，別 途研究する必要がある。また, 思考発話法を使用した 研究では, 研究方法の特性上デー夕数が小さくなる傾 向がある。小規模の発話デー夕から得られた結果の一 般性を高めるために，量的研究を併用できないか，思 考発話法以外の解答プロセスの研究方法を併用できな いかなど，さまざまな研究テーマが考えられる。

\section{テーマ 2 : 混合形式テストにおける等化}

入学者選抜や資格認定などのハイステイクスな決定 に使用されるテストでは, 項目情報の漏洩によって結 果が歪められることを避けるために, 実施回ごとに異 なるテスト版を使用することが通例となっている。そ 
のため，テスト版は 1 つ作成すれば終わりではなく， 継続的に作成し続ける必要がある。新しいテスト版は, テスト仕様（test specifications）と呼ばれる設計書に基づ いて，他のテスト版と性質が等しくなるように作成さ れる (Schmeiser \& Welch, 2006)。作成されるテスト版の性 質が完全に同じであれば，どのテスト版を受験したか に依らず，得点をそのまま比較することができる。し かし現実には，異なる項目で構成されたテスト版を完 全に同じ性質にすることは不可能であり，何らかの違 いが生じることになる。テスト版の性質の違いには, 出題内容, 信頼性, 難易度などさまざまなものがある が, 難易度の違いは直接的に有利・不利を生み出すこ とになるので，公平性の観点から大きな問題となる。 一方で, 出題内容の偏りや信頼性の違いは事後的な対 応が難しいのに対し, 難易度の違いに関しては, ある 程度までは事後的な対応が可能である。データからテ スト版間の難易度の差を推定し, 推定された難易度の 差に応じて各テスト版の得点に調整を加える統計的な プロセスを等化 (equating) と呼ぶ。どのテスト版を受 験しても（測定誤差のランダム変動以外では）結果が変わら ない状態を交換可能 (interchangeable) と呼ぶが, 各テス ト版の得点を調整して交換可能な状態に近づけること が等化の目的である。等化に関する代表的な文献とし て, Holland \& Dorans (2006) および Kolen \& Brennan (2014) が挙げられる。

等化を行う利点は, 年に複数回テストを実施するよ うな場合に，受験者がどの回を受験していても結果を 比較できるようになることである。等化が十分になさ
れていれば，難しいテスト版を受験した場合は上方向 に，易しいテスト版を受験した場合は下方向に得点が 調整されるため, 不公平は生じない。年に一度しか実 施しないテストであっても, 過去の結果と比較して現 在の状況を把握したい場合には, 等化を行うことが望 ましい。選択式テストの等化は方法論がかなりの程度 確立されている一方で, 混合形式テストの等化は研究 の余地が多い分野である。ここでは, 混合形式テスト を等化する際に考慮すべきトピックについて簡単にま とめる。等化には項目反応理論 (item response theory; IRT）を使用する枠組みと, IRTを使用しない古典的な 枠組みがあるが，ここでは等化のイメージをわかりや すくするため, 古典的な枠組みで説明する。IRT 全般 については加藤・山田・川端 (2014), IRTを使った等 化については Kolen \& Brennan (2014) を参照のこと。

\section{トピック 1 : 採点基準の時間的変化の影響}

等化を行うためには, テスト版間の難易度の差を推 定するためのデータが必要になる。代表的なデータ収 集デザイン (等化デザイン) の 1 つは, 新版 (等化したいテ スト版）と旧版（すでに等化されているテスト版）を同一の 受験者群に受験してもらう方法であり，単一群デザイ ン (single group design) と呼ばれる（Kolen \& Brennan, 2014; ここでは, テスト版の受験順についてカウンターバランスをとる 場合も単一群デザインに含める)。単一群デザインを使って 選択式テストの素点 (正答数得点である場合が多い) を等化 する際のイメージを図示したものが Figure 1 の上段で ある。この図において, (1)から(2)で表される部分, つ まり現在の等化研究において新版の素点を旧版の素点

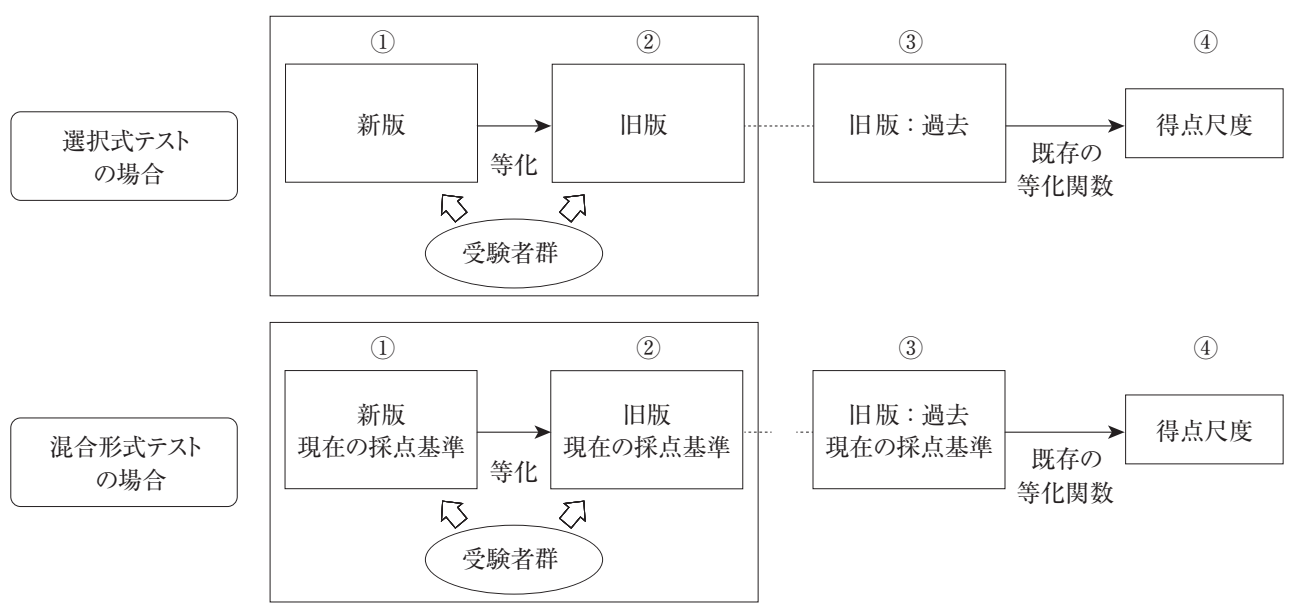

Figure 1 単一群デザインに基づく古典的な等化のイメージ図。上段は選択式テスト，下段は混合形式 テストの場合 
に対応付けるプロセスが狭い意味での等化である（具 体的な等化方法については Kolen \& Brennan, 2014 を参照のこと)。 等化が行われた後は，(1)から(2)への移動が可能になる (等化には対称性があるため, (2)から(1)へ移動も可能になる)。図 中の(3)の旧版は, (2)の旧版と同じテスト版であるが, 過去（旧版を等化した時点）における旧版を表している。 注意しなければならないのは, (2)から(3)への移動であ る。このルートを通るためには, 現在の旧版の性質が, 過去の旧版の性質と同じであることが必要になる。文 言レベルでは完全に同じテスト版なので，性質が同じ であるのは当然と思われがちだが，例えば項目情報が 漏洩していたりすると，テスト版の性質（難易度など） が変化してこのルートを通れなくなってしまう。(2)か ら(3八の移動を可能にするためには, 情報漏洩や経年 劣化を防ぐための品質管理が重要となる。(3)から (4) の移動は, 旧版を等化した際に得られている等化関数 を適用するだけなので，特に困難はない。新版から得 点尺度までの道筋を作ることが広い意味での等化であ る（得点尺度については後述する）。

混合形式テストを等化する場合のイメージを Figure 1 の下段に示した。上段との大きな違いは, 混合形式 テストには記述式項目が含まれるため，テスト版に採 点の要因が加わることである。混合形式テストにおい て素点をどのように計算するかは重要な研究テーマで あるが (Kolen \& Brennan, 2014; Wainer \& Thissen, 1993)，こ こでは適切な方法で素点が得られているものとする。 このとき，単一群デザインを使った新版と旧版の等化 は，基本的には選択式テストの場合と同じように行う ことができる。問題となるのは(2)から(3)への移動であ る。もし採点基準が時間の影響（採点者の入れ替わりや採 点ガイドラインの変更など）で変化している場合には, 現 在の旧版と過去の旧版は同じテスト版とは見なせなく なる。過去に旧版を採点したときの基準を忠実に再現 できるのであれば問題ないが，一般にこれは容易では ない(Fitzpatrick et al., 1998)。採点基準が変化している場
合に，そのことを無視して(2)から(3)へ移動してしまう と，等化結果にバイアスが生じることになる。

このようなとき, Figure 2 に示すような方法で問題 を回避できる。旧版が過去に実施されたときの解答 データを取り出し, 記述式項目を現在の基準で再採点 することで，新たに(3) を作成する。このとき，現在の 旧版と再採点された旧版は項目・採点基準ともに同じ になるので，(2)から(3) への移動が可能になる。その後， 再採点された旧版と過去の採点による旧版の間で等化 を行うことで (単一群デザインになっていることに注意)， (3) から(3)への移動が可能になり，(1)から(4)までの道筋 が完成する。この方法は, Tate (1999) が提案したもの を単一群デザインに基づく古典的な等化の文脈に置き 換えたものである。過去の解答デー夕を再採点するコ ストに加えて，データ管理が煩雑になること，等化の 回数が増えることなど負担も大きいが, 等化のバイア スを減らす効果は高いとされている (Kim, Walker, \& McHale, 2010a, 2010b)。

\section{トピック 2：共通項目を使った等化}

単一群デザインは 2 つテスト版を受験してもらう という性質上, 本試験の中でデータを集めたい場合に は使用しにくい。モニター受験者を募集し, 独立した 等化研究を行う場合に多く用いられる等化デザインで ある。しかし，新版を等化するたびに等化研究を行う のは費用がかかる。また，モニター受験者から得られ た等化結果を, 本試験の受験者に適用できるのかとい う懸念も残る。そのため, 可能であれば，本試験デー 夕を利用して等化を行いたい。本試験データを使った 等化が難しいのは, 一般に新版の受験者群の能力と旧 版の受験者群の能力は等しくないため, テスト版間の 難易度の差と受験者群間の能力差が混ざってしまうか らである。このようなときに, 新版と旧版に同じ項 目 (共通項目) を入れておくことで，等化を可能にする ことができる。基本的には，共通項目における得点差 から群間の能力差を見積もり，その能力差がテスト版

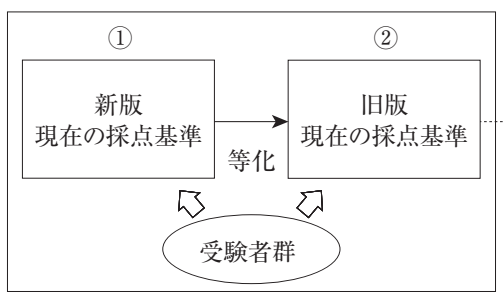

(3)

(4)

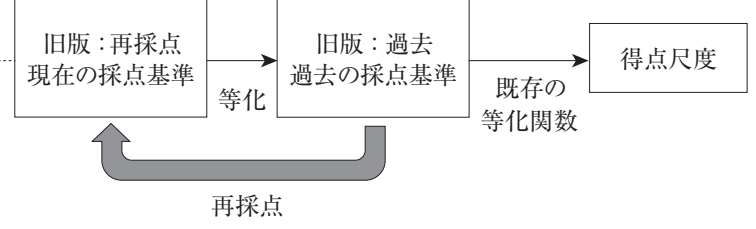

Figure 2 混合形式テストの等化において, 過去の実施時における旧版の記述式項目に対する解答を 再採点した場合。図中の(3)'と(3)間で等化を行うことで，得点尺度までの道筋が完成する 
全体ではどの程度の得点差になるか推測する。観測さ れた素点の差から, 能力差に起因する得点差を差し引 くことで, テスト版間の難易度の差を推定する。こ の等化デザインは共通項目不等価群デザイン (commonitem nonequivalent groups design）などと呼ばれる（Kolen \& Brennan, 2014)。

共通項目を利用した等化では, 共通項目で得られた 情報に基づいてテスト版全体に対する推測を行う。そ のため, 共通項目が測定している内容とテスト版が測 定している内容に違いがある場合, 誤った推測をして しまうことになる。一般に，テスト版が記述式項目を 含むのであれば, 共通項目にも記述式項目を含めるこ とが望ましいとされている。しかし，記述式項目（特 に新規性の高いパフォーマンス型の項目）は選択式項目に比 べて問題内容を覚えやすいため, 情報漏洩のリスクが 高く, 再利用が難しいという問題がある（Haertel \& Linn, 1996; Muraki, Hombo, \& Lee, 2000)。また仮に, 記述式項目 を共通項目として使用できたとしても，採点基準が時 間の影響で変化している場合には, 旧版の記述式の共 通項目について再採点を行う必要が出てくる (共通項目 ではない师版の記述式項目については再採点は不要である)。こ れらの問題を避けるために, 選択式項目のみを共通項 目として使用することが考えられる。この方法は, 選 択式項目と記述式項目が近い内容を測定している場合 にはうまく機能するが，そうでない場合は等化のバイ アスが大きくなる傾向がある (Hagge \& Kolen, 2011; Kim \& Walker, 2012; von Davier \& Wilson, 2008)。共通項目をどのよ うに構成すべきかは, 混合形式テストの等化における 重要な研究テーマの 1 つなっている。

\section{トピック $3:$ 得点尺度への変換}

各テスト版における素点は, 等化による調整が行わ れた後, 得点尺度 (score scale) と呼ばれる尺度上に変 換される (Kolen \& Brennan, 2014)。得点尺度上の得点は 尺度得点（scale score）と呼ばれる。素点がテスト版に 依存したローカルな得点なのに対し, 尺度得点はテス ト版に依存しないグローバルな得点と言える。

得点尺度への変換式は, いちばん最初に作成された テスト版の素点に対して設定されることが多い。この 変換式は単調増加関数であれば任意に決めてよいが, 尺度得点が望ましい性質を持つように工夫を取り入れ ることも可能である。代表的な工夫の 1 つに, 尺度得 点の条件付き測定の標準誤差 (conditional standard error of measurement; CSEM）が， 尺度得点の值によらず一定に なるように変換する方法がある。選択式テストの場合 は素点として正答数得点を使用する場合が多いが, 正
答数得点の CSEM は尺度の中央付近で大きく, 両端で 小さくなる傾向がある。得点によって CSEM の大きさ が変わるため, 測定誤差の影響を正しく評価すること が難しい。Kolen (1988) は正答数得点に逆正弦変換を 適用することでCSEM を一定に近づけ, 測定䛊差の影 響を評価しやすくする方法を提案している。一方, 混 合形式テストの場合は, 記述式項目が多值型であるこ とが多いため, 素点は正答数得点ではないことが多い。 このような場合でも逆正弦変換を適用することは可能 であるが (Ban \& Lee, 2007), 逆正弦変換を使わない新し い変換方法も提案されている (Li, Woodruff, Thompson, \& Wang, 2014; Moses \& Kim, 2017)。得点尺度への変換式を定 めるプロセスは尺度化 (scaling) と呼ばれ, 古典的な等 化において重要な位置を占めるトピックである。また， IRT を使用する場合でも, IRT に基づいて素点を等化 する場合には，関連の深いトピックである。

\section{テーマ 2 のまとめと考察}

混合形式テストでも等化を行うことは可能であるが, 考慮すべき要因は多くなる。単一群デザインによる等 化では，採点基準が時間の経過によって変化している 場合には, 過去の解答デー夕の再採点が必要になる。 共通項目不等価群デザインを用いた等化では, 記述式 項目を共通項目として使いにくいことに加えて, 採点 基準が時間の影響で変化している場合には, 旧版の記 述式の共通項目について再採点が必要になる。共通項 目不等価群デザインにおいて選択式項目のみを共通項 目とする方法は, 2 つの問題を回避できる便利な方法 であるが, 項目形式によって測定内容に差がある場合 には，等化結果にバイアスが生じる恐れがある。記述 式項目の使用が等化に与える影響は, 項目設計, テス 卜設計，等化デザイン，採点方法などによって変わる ため，テストごとに影響を検討する必要がある。

等化を行う際には, 各テスト版が同じ内容（構成概念） を測定していることが求められる (Holland \& Dorans, 2006; Kolen \& Brennan, 2014)。混合形式テストにおいて構 成概念と項目形式の関係をどのようにモデル化するか は，これまで述べてきた技術的な問題とは別の，より 本質的な問題となる。考えられるモデルの 1 つは, 測 定したい構成概念は一次元であり, 選択式項目と記述 式項目はどちらもその次元を測定しているが, 記述式 項目のほうがより複雑な認知プロセスを問う項目が多 い, というものである。この場合は, 項目形式の違い は困難度という形で表現されるので，一次元性を仮定 した等化（古典的な等化や一次元 IRT モデルを使用した等化） が適用できると思われる。2つ目のモデルは, 構成概 
念は一次元であり, どちらの形式の項目もその次元を 測定しているが, 項目形式に固有の効果が存在する, というものである。このとき, 複数の項目形式を使用 する目的は，項目形式の効果を相殺し，構成概念と無 関係な分散の影響を減らすことであると思われる。こ の場合は双因子モデル (bi-factor model; Gibbons \& Hedeker, 1992; 坂本, 2016）の使用が適していると思われるが, 項 目形式の効果がそれほど大きくないのであれば，一次 元性を仮定した等化でも十分に機能すると思われる (Lee \& Lee, 2016)。3つ目のモデルは, 構成概念は多次元 であり，選択式項目と記述式項目はそれぞれ異なる次 元を測定している，というものである。この場合はど ちらの次元も重要な測定対象となるため, 各テスト版 は, 次元間の相関や各次元における信頼性・難易度を 含めて性質が近くなるように作成される必要がある。 テスト版がこの要件を満たせない場合に適切な等化が 行えるのか, 異なる次元における得点をどのように統 合するのかなど，今後の研究が必要な分野である。

\section{テーマ 3: テストの使用がもたらす結果の検証}

あるテストの使用が社会的に認められるためには, そのテストを使用することが何らかの価值を生み出し ている必要がある。もちろん，すべてのテストには プラスの面とマイナスの面があり，何を重視するかに よって判断は変わる。また, 全体としては価值があ る場合でも，特定の個人や下位集団に対して不当なマ イナスの影響を与えるのであれば，やはりそのテスト の使用は認められないことになる。テストの使用がも たらす結果が妥当性の主要な側面であることは，米国 のテストスタンダード（AERA et al., 2014）にも明記され ている。この考えに従えば，テストの開発者および使 用者は, テストの使用によって生じるさまざまな結果 に対して責任を負わなければならないことになる。テ ストの使用に伴う結果を妥当性の範囲に含めることに は反対意見もあるが (e.g., Borsboom, Mellenbergh, \& van Heerden, 2004; Mehrens, 1997; Popham, 1997)， 結果を検証 することの重要性については概ね意見が一致している。 今後は国内においても，テストの使用がもたらす結果 について検証する必要性が高まると思われる。

テストの使用がもたらす結果は多岐にわたっており， 意図して生じるものもあれば，意図しないで生じるも のもある。また，テストの使用が直接的に引き起こす 結果だけでなく，指導や学習に与える影響のような間 接的な結果も検証対象に含まれる (AERA et al., 2014; Haertel, 2013)。そのため, 結果や影響を 1つずつ検証し,
証拠を積み上げていくという方法では，検証がいつま でも終わらない可能性がある。この問題を避けるため に, Kane $(1992,2006,2013)$ の論証ベースの妥当化 (argument-based approach to validation) の考え方が役に立つと思 われる。論証ベースの妥当化の枠組みでは, テスト得 点の解釈および使用を主張と見なし, その主張を構成 するさまざまな推論や仮定が, 証拠によって裏付けら れている程度を吟味する。強い内容を含んだ主張（例 えば，テスト場面で観測された問題解決力から, 日常生活におけ る問題解決力について言及する場合など）や，根拠が不確か な主張ほど，検証の優先度は高くなる。逆に，正しい ことが明らかな主張については，検証の優先度を下げ ることができる。検証に使えるリソースは限られてい るため, 優先度を決めて対応する論証ベースの妥当化 の考え方は，現実的なアプローチであると言える。以 下では，論証ベースの妥当化の考え方を応用し，記述 式項目を含んだテストの使用に関連してどのような結 果や影響を考慮すべきか考える。

\section{検証すべき事項の例}

教育改革とテスト改革がセットで議論されることか らもわかるように, ハイステイクスなテストが指導や 学習に与える影響の大きさは広く認識されている (Frederiksen, 1984; 高大接続システム改革会議, 2016; Resnick \& Resnick, 1992; ただし, Haertel, 1999 はこの影響が過度に強調さ れているとしている)。このことを踏まえれば，高次思考 スキルの測定のために記述式項目を出題するという動 きの中にも，テスト改革を通じた教育改革の狙いがあ ると思われる。ここでは, 記述式項目を出題し, その 結果に基づいてハイステイクスな決定を行うというテ スト使用の背後に，（a）記述式項目を出題することで, 高次思考スキルの正確な測定が可能になる，（b）正確 な測定結果に基づいて授業が見直されることで, 高次 思考スキルの適切な指導が行われるようになる，(c) 適切な指導が行われることで, 生徒の高次思考スキル が向上する，という3つの主張を考える。これらの主 張はあくまでも一例であるが, それぞれの主張を構成 する推論や仮定について考えることで，テストの使用 がもたらす結果や影響として検証すべき事項の例が得 られると思われる。

主張 1 は「テスト得点が高次思考スキルを表すもの と解釈できるか」という妥当性の根幹に関わる主張で ある。もしテスト得点が高次思考スキルを適切に反映 していないのならば，テスト得点に基づく決定は根拠 を失い, 深刻な悪影響をもたらす可能性がある。主 張 1 を構成する中心的な仮定は, 「記述式項目は高次 
思考スキルの測定に適している」という比較的広く受 け入れられている前提であると思われる (e.g., DarlingHammond, 2017)。しかし, 本稿のテーマ 1 でレビューし たところでは，記述式項目であれば高次思考スキルを 測定できるという単純な話ではなく，実際に作成され た項目の特徵に依存することが示されている。非常に 強い内容を含んでいながら，根拠が不確かな主張であ るため, 最優先で検証する必要がある。具体的な検証 方法としては, 項目を試作した段階でプレテストを行 い, 項目の困難度や識別力, 採点の一貫性およびテス 卜得点の信頼性, 特異項目機能の有無などを調べる測 定学的な分析に加えて, 認知プロセスを含めた解答プ ロセス全般について分析することが考えられる。また， 受験者の認知プロセスの違いが解答に反映されている か, 採点者は解答から認知プロセスの違いを見分けら れるか, といった点も, 重要な確認ポイントになると 思われる。もし高次思考スキルを正確に測定できると いう十分な証拠が得られない場合には，項目を再設計 して再びプレテストを行うか, この主張を撤回するこ とが必要になる。

主張 2 は一見すると問題なく成り立つように思える が，正確な測定と適切な指導の間には距離があるため, それほど確かな主張とは言えない。テストがハイステ イクスな決定に使用されるのであれば，学校に対して 指導を促すインセンティブになると予想される。また, 高次思考スキルの正確な測定結果に加えて, 項目例や 採点のためのルーブリックなどが公開されれば，効果 的な指導を行う手助けになると予想される。しかしこ れらはあくまでも仮定であるため, 実際に指導の改善 につながったかについては，別途検証する必要がある。 逆に，テストがハイステイクスであることで，学校で の指導がテスト対策の方向に歪められる可能性もある (Frederiksen, 1984; Resnick \& Resnick, 1992)。一例としては, 高次認知スキルの指導に多くの時間が割り当てられる ことで，基礎的な知識や技能の習得が疎かになる場合 が考えられる。また, 解法パターンを丸暗記するなど の，妥当性を劦かすような指導がなされる可能性もあ る。過度のテスト対策によって悪影響が生じていない か調査することは，優先度が高い検証事項であると思 われる。

主張 3 も一見すると問題なく成り立つように思える が, 教師が適切な指導を行ったとしても, 学習者が十 分な努力をしなければ高次思考スキルの向上にはつな がらないため, やはり不確かな主張である。大学入試 などのハイステイクスなテストで高次思考スキルが問
われることになれば, 生徒の学習意欲は高まると予想 される。一方, 主張 2 の場合と同様に, 学習がテスト 対策中心になってしまう可能性もある。真正性の高い テストの場合には，テスト対策は肯定的な影響をもた らすという主張もあるが (Wiggins, 1989), 記述式項目を 使用しているというだけでは，そのような効果は薄い と思われる (Haertel, 1999)。実際に生徒の高次思考スキ ルが向上しているのか, テスト対策で得点が上がって いるだけなのかについては，テストの使用が意図した 効果をもたらしたか総括的に評価する部分であるので, 優先度の高い検証事項である。このとき, 集団全体と しては高次思考スキルが向上していると示された場合 でも，特定の下位集団では向上していない可能性があ る。また，ある教科における高次思考スキルが向上す る一方で, 他教科の学力が犠牲になっている可能性も ある。検証においては, 望ましくない可能性を積極的 に考え, それらの可能性を証拠に基づいて否定してい くことが効果的である。

\section{論証ベースの妥当化に関する補足}

論証ベースの妥当化において, テスト得点の解釈お よび使用に内在する推論や仮定を明らかにするプロセ スは，解釈および使用の論証（interpretation/use argument; IUA）と呼ばれる (Kane, 2013)。Kane (2013) は IUA の使 用を, テスト得点に基づいた決定ルールの適切さや, 決定がもたらす直接的な結果について検証する場合に 限定しており，テストの使用がもたらす社会的な影響 を検証する文脈で使用することには消極的なように思 える。一方 Lane (2014) は, テストの使用がもたらすさ まざまな結果や影響を扱うために IUAの使用を提案し ている。本テーマでの試みは, Lane (2014) の考えに近 いものである。

\section{テーマ 3 のまとめと考察}

米国のテストスタンダードでは，テストの使用がも たらす結果や影響は妥当性の範囲に含まれ, 開発者お よび使用者が責任をもって検証すべき事項になってい る（AERA et al., 2014）。ここでは, 教育改革の目的で記述 式項目を含んだテストを使用するような場面を想定し， 開発者および使用者が検証すべき事項について, 論証 ベースの妥当化 (e.g., Kane, 2013) の考え方を応用して 考察した。主張という比較的捉えやすいものから, そ の背後にある推論や仮定について考えていく論証べー スの妥当化の枠組みは, 検証事項を明確にする上で役 に立つと思われる。しかし，検証事項を明確にできて も，実際に検証を行うのは容易ではない。検証すべき 内容は多岐にわたるため, 研究の計画からデータの収 
集，分析および結果の考察まで適切に行うためには, かなりの研究リソースを必要とする。また, 妥当性を 損なう可能性のある検証事項については, 開発者・使 用者ともに積極的には研究しにくいという事情がある (Haertel, 2013)。テストの使用がもたらす結果や影響の 検証が進むためには，そのような検証の必要性を利害 関係者が正しく認識し，開発者や使用者に積極的に働 きかけていくことが重要になる。また，妥当性を低め るような結果であっても, それを公開した上で, 改善 に向けた議論ができるような社会的理解が求められる。

\section{全体考察}

本稿では，記述式項目を使用する上で考慮すべき教 育測定学的なテーマの中から 3 つを選んで考察した。 高次思考スキルを測定するために記述式項目が重視さ れる傾向は，日本と米国で類似していると言える。研 究が先行している米国の動向を参考にすることは, 今 後必要になる研究を明らかにする上で役に立つと思わ れる。

一方で, 日米には大きな違いも存在する。日本で記 述式項目の使用が検討されているのは大学入試におけ る共通テストであるが，米国で記述式および革新的な 項目の使用が進められているのはNAEP, PARCC, Smarter Balanced などのモニタリングやアカウンタビ リティ向上を目的としたテストである。これらは政策 決定者や教育関係者にとって特に重要なテストである が，大学入試のように受験者に直接的な影響を与える テストとは異なる。米国の大学入試で広く用いられて いる SATは, 2016 年の改定でエッセイを任意に切り 替えている（College Board, 2015）。また, 全米共通学力基 準に準拠した内容にする計画も中断されており (Zwick, 2017)，むしろ従来型の選択式テストに回帰しつつある ようにも見える。大塚・柴山・植阪・遠藤・野口 （2018）において大塚が指摘しているように，調査と選 抜という目的の違いを正しく認識しないと, 議論を間 違える恐れがある。

日米のもう 1 つの違いは, 米国では指導や学習に資 するアセスメントの開発という目的が明確に存在する ことである (Bennett, 2015; Gordon Commission on the Future of Assessment in Education, 2013; Russell \& Markle, 2017)。指導 や学習に役に立つアセスメントでは, 学習者の意欲を 引き出すための工夫や, 学習者の状態に合わせて適切 なフィードバックを返すための項目選択, 記述式項目 を含む場合でも即時に結果を返却できる自動採点シス テムなど, さまざまな機能が求められる。これらは客
観性, 公平性, 比較可能性といった測定学的な性質を 脅かすものであるが，両者のバランスを取るための方 法が模索されている (Drasgow, 2016)。一方国内では，大 学入試という客観性や公平性が最優先となるテストが 議論の中心になっているために, 革新的な測定技術の 研究を促すような動きは限られている。この分野にお いて, 国内の教育測定学が立ち遅れることが懸念され る。

本稿では, 各テーマの考察において妥当性との関連 を重視した。村山（2012）は国内において心理測定学的 なトピックと妥当性を関連付けた議論が少ないことを 指摘しているが，教育測定においても同様の傾向が見 られる。村山（2012）の指摘後, 妥当性を重視した議論 は増えつつあるように思われるが (e.g., 石井, 2014; 宇佐美, 2013a, 2016), 数としてはまだ十分ではない。本稿の試 みは，このような状況を踏まえてのものである。

妥当性は,さまざまなトピックと密接に関連した教 育測定学の中心的な概念である。妥当性と関連付ける ことで, 個々の研究や議論の位置付けが明確になり, 理解が深まることが期待される。しかし，そのような 効果が得られるためには, 基準となる妥当性概念につ いて研究者間でコンセンサスが得られている必要があ る。現在主流の妥当性の枠組みは, Messick (1989) お よび Kane (2006) に基づくものであるが, 主流派の中 でも意見が一致しているわけではない。また，新しい 妥当性の考え方も提案されるようになっており（e.g., Borsboom et al., 2004; Lissitz \& Samuelsen, 2007), 教育測定の 専門家でも全体像を把握することが難しくなってきて いる。吉田・石井・南風原 (2012) の中で南風原は, 質 問紙尺度の作成と使用という文脈において, 妥当性を 単純明快に概念化することが, 尺度作成の目標の明確 化につながり, 結果として研究実践が改善される可能 性を指摘している。基準となる妥当性概念を定めてい くことは, 国内の教育測定学における今後の課題にな ると思われる。

最後になるが，本稿で取り上げたのは記述式項目を 使用する際に考慮すべきテーマの一部であり，これら 以外にも重要なテーマは多数存在する。特に, 採点の 正確さおよびテストの信頼性は, 妥当性の前提となる 極めて重要なテーマである。国内でも比較的多くの 研究がなされているので，それらを参考にしてもら いたい (e.g., 平井, 2006, 2007; 大久保, 2013; 柴山・前田・佐藤, 2010; 平 ·江上, 1992; 宇佐美, 2008, 2010, 2011, 2013b; 宇都 · 植 野, 2016; 渡部・平・井上, 1988; 自動採点の最新の動向については, 石岡・劉・峯, 2018)。記述式項目をはじめ, 革新的な項目 
の使用が増えてきている現在の状況は, 教育測定の理 論を強化し, 研究領域を拡大する機会でもある。Snow (1993) は, 項目形式を含めた多くの測定学的な問いに 答えるためには，認知プロセスの研究やテストの使用 が指導・学習に与える影響の研究に加えて, 受験者の 態度や意欲, テスト不安なども対象に含めたテストデ ザインの心理学を発達させるべきだと主張した。測定 したい構成概念が複雑化し，テストに求められる役割 が変化する中, 教育測定学が多くの現実的な課題に対 応できるように拡張されることが求められる。

\section{引用文献}

Ackerman, T. A., \& Smith, P. L. (1988). A comparison of the information provided by essay, multiple-choice, and free-response writing tests. Applied Psychological Measurement, 12, 117-128. doi:10.1177/01466216880 1200202

Agard, C., \& von Davier, A. A. (2018). The virtual world and reality of testing: Building virtual assessments. In H. Jiao \& R. W. Lissitz (Eds.), Technology enhanced innovative assessment: Development, modeling, and scoring from an interdisciplinary perspective (pp. 1-29). Charlotte, NC: Information Age Publishing, Inc.

American Educational Research Association [AERA], American Psychological Association [APA], \& National Council on Measurement in Education [NCME]. (2014). Standards for educational and psychological testing. Washington, DC: AERA.

Ban, J., \& Lee, W. (2007). Defining a score scale in relation to measurement error for mixed format tests (CASMA Research Report Number 24). Iowa City, IA: Center for Advanced Studies in Measurement and Assessment, The University of Iowa.

Baxter, G. P., Glaser, R., \& Raghavan, K. (1994). Analysis of cognitive demand in selected alternative science assessments (CSE Technical Report 382). Los Angeles, CA: National Center for Research on Evaluation, Standards, and Student Testing, University of California, Los Angeles.

Bejar, I. I. (2017). A historical survey of research regarding constructed-response formats. In R. E. Bennett \& M. von Davier (Eds.), Advancing human assessment: The methodological, psychological and policy contributions of ETS (pp. 565-633). Cham,
Switzerland: Springer International Publishing AG.

Bennett, R. E. (1993). On the meanings of constructed response. In R. E. Bennett \& W. C. Ward (Eds.), Construction versus choice in cognitive measurement: Issues in constructed response, performance testing, and portfolio assessment (pp. 1-27). Hillsdale, NJ: Lawrence Erlbaum Associates, Publishers.

Bennett, R. E. (2015). The changing nature of educational assessment. Review of Research in Education, 39, 370-407. doi:10.3102/0091732X14554179

Bennett, R. E., Rock, D. A., \& Wang, M. (1991). Equivalence of free-response and multiple-choice items. Journal of Educational Measurement, 28, 77-92. doi: 10.1111/j.1745-3984.1991.tb00345.x

Bennett, R. E., Ward, W. C., Rock, D. A., \& LaHart, C. (1990). Toward a framework for constructed-response items (ETS RR-90-7). Princeton, NJ: Educational Testing Service.

Bloom, B. S. (Ed.), Engelhart, M. D., Furst, E. J., Hill, W. H., \& Krathwohl, D. R. (1956). Taxonomy of educational objectives: The classification of educational goals. Handbook 1: Cognitive domain. New York: David McKay Company, Inc.

Borsboom, D., Mellenbergh, G. J., \& van Heerden, J. (2004). The concept of validity. Psychological Review, 111, 1061-1071. doi:10.1037/0033-295X.111. 4.1061

Brennan, R. L., \& Johnson, E. G. (1995). Generalizability of performance assessments. Educational Measurement: Issues and Practice, 14, 9-12. doi:10.1111/ j.1745-3992.1995.tb00882.x

Bridgeman, B. (2016). Can a two-question test be reliable and valid for predicting academic outcomes? Educational Measurement: Issues and Practice, 35, 21-24. doi:10.1111/emip.12130

College Board (2015). Test specifications for the redesigned $S A T^{\circledR}$. New York: The College Board. Retrieved from https://collegereadiness.collegeboard. org/pdf/test-specifications-redesigned-sat-1.pdf (December 8, 2018.)

中央教育審議会 (2014). 新しい時代にふさわしい高大 接続の実現に向けた高等学校教育, 大学教育, 大学 入学者選抜の一体的改革について一すべての若者が 夢や目標を芽吹かせ, 未来に花開かせるために（答 申) 文部科学省 Retrieved from http://www.mext. 
go.jp/b_menu/shingi/chukyo/chukyo0/toushin/__ icsFiles/afieldfile/2015/01/14/1354191.pdf（2018 年 11 月 20 日)

Darling-Hammond, L. (2014) . Introduction: The rationale and context for performance assessment. In L. Darling-Hammond \& F. Adamson (Eds.), Beyond the bubble test: How performance assessments support 21st century learning (pp. 1-14). San Francisco, CA: Jossey-Bass.

Darling-Hammond, L. (2017). Developing and measuring higher order skills: Models for state performance assessment systems. Palo Alto, CA: Learning Policy Institute. Retrieved from https://learningpolicyinstitute. org/sites/default/files/product-files/Models_State_ Performance_Assessment_Systems_REPORT.pdf (January 22, 2019.)

Drasgow, F. (Ed.) (2016). Technology and testing: Improving educational and psychological measurement. New York: Routledge.

Dunbar, S. B., Koretz, D. M., \& Hoover, H. D. (1991). Quality control in the development and use of performance assessments. Applied Measurement in Education, 4, 289-303. doi:10.1207/s15324818ame0404_3

Ercikan, K., \& Pellegrino, J. W. (Eds.). (2017). Validation of score meaning for the next generation of assessments: The use of response processes. New York: Routledge.

Farr, R., Pritchard, R., \& Smitten, B. (1990). A description of what happens when an examinee takes a multiple-choice reading comprehension test. Journal of Educational Measurement, 27, 209-226. doi:10. 1111/j.1745-3984.1990.tb00744.x

Fitzpatrick, A. R., Ercikan, K., Yen, W. M., \& Ferrara, S. (1998). The consistency between raters scoring in different test years. Applied Measurement in Education, 11, 195-208. doi:10.1207/s15324818ame1102_5

Frederiksen, N. (1984). The real test bias: Influences of testing on teaching and learning. American Psychologist, 39, 193-202. doi:10.1037/0003-066X.39.3.193

Frederiksen, N., \& Ward, W. C. (1978). Measures for the study of creativity in scientific problem-solving. Applied Psychological Measurement, 2, 1-24. doi:10. 1177/014662167800200101

Gao, X., Shavelson, R. J., \& Baxter, G. P. (1994). Generalizability of large-scale performance assessments in science: Promises and problems. Applied Measurement in Education, 7, 323-342. doi:10.1207/s15324818 ame0704_4

Gibbons, R. D., \& Hedeker, D. R. (1992). Full-information item bi-factor analysis. Psychometrika, 57, 423436. doi:10.1007/BF02295430

Gordon Commission on the Future of Assessment in Education. (2013). A public policy statement. Princeton, NJ: The Gordon Commission on the Future of Assessment in Education. Retrieved from https://www.ets.org/Media/Research/pdf/gordon_ commission_public_policy_report.pdf (January 22, 2019.)

Haertel, E. (2013). How is testing supposed to improve schooling? Measurement: Interdisciplinary Research and Perspectives, 11, 1-18. doi:10.1080/15366367. 2013.783752

Haertel, E. H. (1999). Performance assessment and education reform. Phi Delta Kappan, 80, 662-666.

Haertel, E. H., \& Linn, R. L. (1996). Comparability. In G. W. Phillips (Ed.), Technical issues in large-scale performance assessment (NCES 96-802) (pp. 59-78). Washington, DC: National Center for Education Statistics, U. S. Department of Education.

Hagge, S. L., \& Kolen, M. J. (2011). Equating mixedformat tests with format representative and non-representative common items. In M. J. Kolen \& W. Lee (Eds.), Mixed-format tests: Psychometric properties with a primary focus on equating. Vol. 1 (CASMA Monograph Number 2.1) (pp. 95-135). Iowa City, IA: Center for Advanced Studies in Measurement and Assessment, The University of Iowa.

Haladyna, T. M., \& Rodriguez, M. C. (2013). Developing and validating test items. New York: Routledge.

Hamilton, L. S., Nussbaum, E. M., \& Snow, R. E. (1997). Interview procedures for validating science assessments. Applied Measurement in Education, 10, 181-200. doi:10.1207/s15324818ame1002_5

Hancock, G. R. (1994). Cognitive complexity and the comparability of multiple-choice and constructedresponse test formats. The Journal of Experimental Education, 62, 143-157. doi:10.1080/00220973.1994.9 943836

平井洋子 (2006).パフォーマンス・アセスメントによ る高次思考能力の測定の研究 平成 14 年度-平成 16 
年度科学研究費成果報告書（課題番号 14510158, 基 盤研究 (C) (2), 研究代表者 平井洋子)

平井洋子 (2007). 主観的評定に扔ける評定基準, 評定 者数, 課題数の効果について一一般化可能性理論に よる定量的研究 人文学報, 380, 25-64.

Hogan, T. P. (1981). Relationship between free-response and choice-type tests of achievement: A review of the literature. Green Bay, WI: University of Wisconsin. (ERIC Document Reproduction Service No. ED 224 811)

Holland, P. W., \& Dorans, N. J. (2006). Linking and equating. In R. L. Brennan (Ed.), Educational measurement (4th ed., pp. 187-220). Westport, CT: American Council on Education and Praeger.

石井秀宗 (2014). 本邦に扮ける測定・評価研究の動 向一構成概念を精確に測定することの重要性の再認 識を目指して 教育心理学年報, 53, 70-82. doi:10. 5926/arepj.53.70

石岡恒憲・劉 東岳・峯 恒憲 (2018). エッセイおよび 論述解答試験採点に関する最近の話題と自動採点に むけた現在の技術水準 日本テスト学会第 16 回大会 発表論文抄録集, 124-127.

Johnson, R. L., Penny, J. A., \& Gordon, B. (2009). Assessing performance: Designing, scoring, and validating performance tasks. New York: The Guilford Press.

Kane, M. T. (1992). An argument-based approach to validity. Psychological Bulletin, 112, 527-535. doi:10. 1037/0033-2909.112.3.527

Kane, M. T. (2006). Validation. In R. L. Brennan (Ed.), Educational measurement (4th ed., pp. 17-64). Westport, CT: American Council on Education and Praeger.

Kane, M. T. (2013). Validating the interpretations and uses of test scores. Journal of Educational Measurement, 50, 1-73. doi:10.1111/jedm.12000

加藤健太郎 - 山田剛史 · 川端一光 (2014). R による項 目反応理論 オーム社

Katz, I. R., Bennett, R. E., \& Berger, A. E. (2000). Effects of response format on difficulty of SATMathematics items: It's not the strategy. Journal of Educational Measurement, 37, 39-57. doi:10.1111/ j.1745-3984.2000.tb01075.x

Kim, S., \& Walker, M. (2012). Determining the anchor composition for a mixed-format test: Evaluation of subpopulation invariance of linking functions. Applied Measurement in Education, 25, 178-195. doi: 10.1080/08957347.2010.524720

Kim, S., Walker, M. E., \& McHale, F. (2010a). Comparisons among designs for equating mixed-format tests in large-scale assessments. Journal of Educational Measurement, 47, 36-53. doi:10.1111/j.17453984.2009.00098.x

Kim, S., Walker, M. E., \& McHale, F. (2010b). Investigating the effectiveness of equating designs for constructed-response tests in large-scale assessments. Journal of Educational Measurement, 47, 186-201. doi:10.1111/j.1745-3984.2010.00108.x

Kolen, M. J. (1988). Defining score scales in relation to measurement error. Journal of Educational Measurement, 25, 97-110. doi:10.1111/j.1745-3984.1988. tb00295.x

Kolen, M. J., \& Brennan, R. L. (2014). Test equating, scaling, and linking: Methods and practices (3rd ed.). New York: Springer.

高大接続システム改革会議 (2016). 高大接続システム 改革会議「最終報告」文部科学省 Retrieved from http://www.mext.go.jp/component/b_menu/shingi/ toushin/__icsFiles/afieldfile/2016/06/02/1369232_ 01_2.pdf (2018 年 11 月 20 日)

Lane, S. (2014). Validity evidence based on testing consequences. Psicothema, 26, 127-135. doi:10.7334/ psicothema2013.258

Lee G., \& Lee, W. (2016). Bi-factor MIRT observedscore equating for mixed-format tests. Applied Measurement in Education, 29, 224-241. doi:10.1080/0895 7347.2016.1171770

Leighton, J. P. (2004) . Avoiding misconception, misuse, and missed opportunities: The collection of verbal reports in educational achievement testing. Educational Measurement: Issues and Practice, 23, 6-15. doi:10.1111/j.1745-3992.2004.tb00164.x

Li, D., Woodruff, D., Thompson, T. D., \& Wang, H. (2014). A general method to achieve constant conditional standard error of measurement. Paper presented at the annual meeting of the National Council on Measurement in Education, Philadelphia, PA.

Lissitz, R. W., \& Samuelsen, K. (2007). A suggested change in terminology and emphasis regarding validity and education. Educational Researcher, 36, 437- 
448. doi:10.3102/0013189X07311286

Magone, M. E., Cai, J., Silver, E. A., \& Wang, N. (1994). Validating the cognitive complexity and content quality of a mathematics performance assessment. International Journal of Educational Research, 21, 317-340. doi:10.1016/S0883-0355(06) 80022-4

Martinez, M. E. (1999). Cognition and the question of test item format. Educational Psychologist, 34, 207218. doi:10.1207/s15326985ep3404_2

益川弘如 - 白水 始 - 根本紘志 - 一柳智紀 - 北澤 武 河㟝美保（2018）. 思考発話法を用いた多肢選択式問 題の解決プロセスの解明一大学入試センター試験問 題の国語既出問題を活用して 日本テスト学会誌, 14, 51-70. doi:10.24690/jart.14.1_51

Mehrens, W. A. (1997). The consequences of consequential validity. Educational Measurement: Issues and Practice, 16, 16-18. doi:10.1111/j.1745-3992.1997. tb00588.x

Messick, S. (1989). Validity. In R. L. Linn (Ed.), Educational measurement (3rd ed., pp. 13-103). New York: American Council on Education and Macmillan.

Messick, S. (1993). Trait equivalence as construct validity of score interpretation across multiple methods of measurement. In R. E. Bennett \& W. C. Ward (Eds.), Construction versus choice in cognitive measurement: Issues in constructed response, performance testing, and portfolio assessment (pp. 61-73). Hillsdale, NJ: Lawrence Erlbaum Associates.

文部科学省 (2017). 大学入学共通テスト実施方針 文 部科学省 Retrieved from http://www.mext.go.jp/ component/a_menu/education/micro_detail/_ icsFiles/afieldfile/2017/10/24/1397731_001.pdf (2018 年 11 月 20 日)

Moses, T., \& Kim, Y. (2017). Stabilizing conditional standard errors of measurement in scale score transformations. Journal of Educational Measurement, 54, 184-199. doi:10.1111/jedm.12140

Muraki, E., Hombo, C. M., \& Lee, Y.-W. (2000). Equating and linking of performance assessments. Applied Psychological Measurement, 24, 325-337. doi:10.1177/01466210022031787

村山 航 (2012). 妥当性一概念の歴史的変遷と心理測 定学的観点からの考察 教育心理学年報, 51, 118130. doi:10.5926/arepj.51.118
Norris, S. P. (1990). Effect of eliciting verbal reports of thinking on critical thinking test performance. Journal of Educational Measurement, 27, 41-58. doi:10. 1111/j.1745-3984.1990.tb00733.x

大久保智哉 (2013). 400 字論述課題における能力測定 の信頼性 大学入試センター研究紀要, 42, 1-12.

大塚雄作 - 柴山 直 - 植阪友理 - 遠藤利彦 - 野口裕之 (2018). 学力の評価と測定をめぐって 教育心理学 年報, 57, 209-229. doi:10.5926/arepj.57.209

Popham, W. J. (1997). Consequential validity: Right concern-wrong concept. Educational Measurement: Issues and Practice, 16, 9-13. doi:10.1111/ j.1745-3992.1997.tb00586.x

Reich, G. A. (2009). Testing historical knowledge: Standards, multiple-choice questions and student reasoning. Theory \& Research in Social Education, 37, 325-360. doi:10.1080/00933104.2009.10473401

Reich, G. A. (2013). Imperfect models, imperfect conclusions: An exploratory study of multiple-choice tests and historical knowledge. The Journal of Social Studies Research, 37, 3-16. doi:10.1016/j.jssr.2012. 12.004

Resnick, L. B., \& Resnick, D. P. (1992). Assessing the thinking curriculum: New tools for educational reform. In B. R. Gifford \& M. C. O'Connor (Eds.), Changing assessments: Alternative views of aptitude, achievement and instruction (pp. 37-75). Norwell, MA: Kluwer Academic Publishers.

Rodriguez, M. C. (2003). Construct equivalence of multiple-choice and constructed-response items: A random effects synthesis of correlations. Journal of Educational Measurement, 40, 163-184. doi:10.1111/ j.1745-3984.2003.tb01102.x

Rupp, A. A., Ferne, T., \& Choi, H. (2006). How assessing reading comprehension with multiple-choice questions shapes the construct: A cognitive processing perspective. Language Testing, 23, 441-474. doi: 10.1191/02655322061t337oa

Russell, J., \& Markle, R. (2017). Continuing a culture of evidence: Assessment for improvement (ETS RR-1708). Princeton, NJ: Educational Testing Service.

坂本佑太朗 (2016).わが国の TIMSS2011 数学データ

における多次元 IRTを使った妥当性の検証について 日本テスト学会誌, 12, 37-53.

Schmeiser, C. B., \& Welch, C. J. (2006). Test 
development. In R. L. Brennan (Ed.), Educational measurement (4th ed., pp. 307-353). Westport, CT: American Council on Education and Praeger.

Schraw, G., McCrudden, M. T., Lehman, S., \& Hoffman, B. (2011). An overview of thinking skills. In G. Schraw \& D. R. Robinson (Eds.), Assessment of higher order thinking skills (pp. 19-45). Charlotte, NC: Information Age Publishing, Inc.

Shavelson, R. J., Baxter, G. P., \& Gao, X. (1993). Sampling variability of performance assessments. Journal of Educational Measurement, 30, 215-232. doi: 10.1111/j.1745-3984.1993.tb00424.x

柴山 直・前田忠彦・佐藤喜一 (2010). 論述式試験の 採点デザインと信頼性評価に関する統計的研究（統 計数理研究所共同研究リポート 244） 統計数理研究 所

Smith, M., Breakstone, J., \& Wineburg, S. (2018). History assessments of thinking: A validity study. Cognition and Instruction. Advance online publication. doi:10.1080/07370008.2018.1499646

Smith, M. D. (2017). Cognitive validity: Can multiplechoice items tap historical thinking processes? American Educational Research Journal, 54, 12561287. doi:10.3102/0002831217717949

Smith, M. D. (2018). New multiple-choice measures of historical thinking: An investigation of cognitive validity. Theory \& Research in Social Education, 46, 1-34. doi:10.1080/00933104.2017.1351412

Snow, R. E. (1993). Construct validity and constructedresponse tests. In R. E. Bennett \& W. C. Ward (Eds.), Construction versus choice in cognitive measurement: Issues in constructed response, performance testing, and portfolio assessment (pp. 45-60). Hillsdale, NJ: Lawrence Erlbaum Associates.

Stecher, B. (2014). Looking back: Performance assessment in an era of standards-based educational accountability. In L. Darling-Hammond \& F. Adamson (Eds.), Beyond the bubble test: How performance assessments support 21st century learning (pp. 17-52). San Francisco, CA: Jossey-Bass.

平 直樹 ·江上由実子 (1992). ESSAY TEST の方法論 的諸問題に関する研究の動向について 教育心理学 研究, 40, 108-117. doi:10.5926/jjep1953.40.1_108

Tate, R. (1999). A cautionary note on IRT-based linking of tests with polytomous items. Journal of Educa- tional Measurement, 36, 336-346. doi:10.1111/j.17453984.1999.tb00560.x

Thissen, D., Wainer, H., \& Wang, X. (1994). Are tests comprising both multiple-choice and free-response items necessarily less unidimensional than multiplechoice tests? An analysis of two tests. Journal of Educational Measurement, 31, 113-123. doi:10.1111/ j.1745-3984.1994.tb00437.x

Traub, R. E. (1993). On the equivalence of the traits assessed by multiple-choice and constructed-response tests. In R. E. Bennett \& W. C. Ward (Eds.), Construction versus choice in cognitive measurement: Issues in constructed response, performance testing, and portfolio assessment (pp. 29-44). Hillsdale, NJ: Lawrence Erlbaum Associates.

Traub, R. E., \& Fisher, C. W. (1977). On the equivalence of constructed-response and multiple-choice tests. Applied Psychological Measurement, 1, 355369. doi:10.1177/014662167700100304

宇佐美 慧 (2008). 小論文試験の採点における文字の 美醜効果の規定因一メ夕分析および実験による検討 日本テスト学会誌, 4, 73-83.

宇佐美 慧 (2010). 採点者側と受験者側のバイアス要 因の影響を同時に評価する多值型項目反応モデル— MCMCアルゴリズムに基づく推定 教育心理学研 究, 58, 163-175. doi:10.5926/jjep.58.163

宇佐美 慧 (2011). 小論文評価データの統計解析一制 限字数を考慮した測定論的課題の検討 行動計量学, 38, 33-50. doi:10.2333/jbhmk.38.33

宇佐美 慧 (2013a). 論述式テストの運用における測定 論的問題とその対処 日本テスト学会誌, 9, 145-164. 宇佐美 慧 (2013b). 論述式テストを通した評価と選抜 の信頼性に関わる諸要因の影響力についての定量的 比較検討 日本教育工学会論文誌, 36, 451-464. doi:10.15077/jjet.KJ00008609390

宇佐美 慧 (2016). 測定 ・評価 - 研究法に関する研究 の動向と展望一教育測定 - 心理統計の専門家の不 足および心理統計教育の問題の再考と「専門家に よる専門家の育成」の必要性 教育心理学年報, 55 , 83-100. doi:10.5926/arepj.55.83

宇都雅輝・植野真臣 (2016). パフォーマンス評価のた めの項目反応モデルの比較と展望 日本テスト学会 誌, $12,55-75$.

van den Bergh, H. (1990). On the construct validity of multiple-choice items for reading comprehension. 
Applied Psychological Measurement, 14, 1-12. doi:10. 1177/014662169001400101

von Davier, A. A., \& Wilson, C. (2008). Investigating the population sensitivity assumption of item response theory true-score equating across two subgroups of examinees and two test formats. Applied Psychological Measurement, 32, 11-26. doi:10.1177/01466216073 11560

Wainer, H., \& Thissen, D. (1993). Combining multiplechoice and constructed-response test scores: Toward a Marxist theory of test construction. Applied Measurement in Education, 6, 103-118. doi:10.1207/ s15324818ame0602_1

Ward, W. C., Frederiksen, N., \& Carlson, S. B. (1980). Construct validity of free-response and machinescorable forms of a test. Journal of Educational
Measurement, 17, 11-29. doi:10.1111/j.1745-3984. 1980.tb00811.x

渡部 洋 - 平 由美子 - 井上俊哉 (1988). 小論文評価 デー夕の解析 東京大学教育学部紀要, 28, 143-164.

Wiggins, G. (1989). Teaching to the (authentic) test. Educational Leadership, 46, 41-47.

吉田寿夫 - 石井秀宗・南風原朝和 (2012). 尺度の作 成・使用と妥当性の検討 教育心理学年報, 51, 213217. doi:10.5926/arepj.51.213

Zumbo, B. D., \& Hubley, A. M. (Eds.). (2017). Understanding and investigating response processes in validation research. Cham, Switzerland: Springer International Publishing AG.

Zwick, R. (2017). Who gets in? Strategies for fair and effective college admissions. Cambridge, MA: Harvard University Press. 